\title{
Using CD4 Percentage and Age to Optimize Pediatric Antiretroviral Therapy Initiation
}

WHAT'S KNOWN ON THIS SUBJECT: In HIV-infected children, decisions to start antiretroviral therapy must weigh immunologic benefits against potential risks. Current guidelines recommend using CD4 percentage and age when deciding to start treatment. Population-level effects of these factors on immunologic recovery are unknown.

WHAT THIS STUDY ADDS: Starting antiretroviral therapy at higher CD4 percentages and younger ages maximizes potential for immunologic recovery. However, not all benefits are sustained, and viral failure may occur. Our results help clinicians better weigh immunologic benefits against viral failure risks.
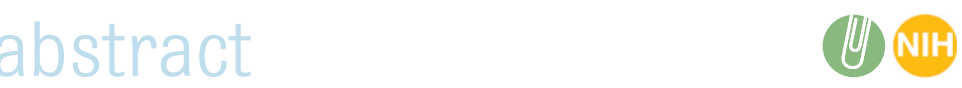

BACKGROUND: Quantifying pediatric immunologic recovery by highly active antiretroviral therapy (HAART) initiation at different CD4 percentage (CD4\%) and age thresholds may inform decisions about timing of treatment initiation.

METHODS: HIV-1-infected, HAART-naive children in Europe and the Americas were followed from 2002 through 2009 in PENPACT-1. Data from 162 vertically infected children, with at least World Health Organization "mild" immunosuppression and CD4\% < 10 th percentile, were analyzed for improvement to a normal CD4\% ( $\geq 10$ th percentile) within 4 years after HAART initiation. Data from 209 vertically infected children, regardless of immune status, were analyzed for CD4\% outcomes at 4 years and viral failure within 4 years.

RESULTS: Seventy-two percent of baseline immunosuppressed children recovered to normal within 4 years. Compared with "severe" immunosuppression, more children with "mild" immunosuppression (difference $36 \%$, 95\% confidence interval [CI]: $22 \%$ to $49 \%$ ) or "advanced" immunosuppression (difference $20.8 \%, 95 \% \mathrm{Cl}$ : $5.8 \%$ to $35.9 \%$ ) recovered a normal CD4\%. For each 5-year increase in baseline age, the proportion of children achieving a normal CD4\% declined by $19 \%$ (95\% $\mathrm{Cl}: 11 \%$ to $27 \%)$. Combining baseline CD4\% and age effects resulted in $>90 \%$ recovery when initiating HAART with "mild" immunosuppression at any age or "advanced" immunosuppression at age $<3$ years. Baseline CD4\% effects became greater with increasing age $(P=.02)$. At 4 years, most immunologic benefits were still significant but diminished. Viral failure was highest in infancy (56\%) and adolescence (63\%).

CONCLUSIONS: Initiating HAART at higher CD4\% and younger ages maximizes potential for immunologic recovery. Guidelines should weigh immunologic benefits against long-term risks. Pediatrics 2014;134:e1104-e1116
AUTHORS: Dwight E. Yin, MD, MPH, ${ }^{a, b, c}$ Meredith G. Warshaw, MSS, MA, ${ }^{d}$ William C. Miller, MD, PhD, MPH, ${ }^{\text {bee }}$ Hannah Castro, MSc, ${ }^{f}$ Susan A. Fiscus, PhD, ${ }^{\circ}$ Lynda M.

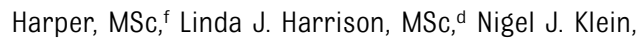
MBBS, ${ }^{h}$ Joanna Lewis, PhD, ${ }^{i}$ Ann J. Melvin, MD, MPH, ${ }^{j}$ Gareth Tudor-Williams, MD, ${ }^{k}$ and Ross E. McKinney Jr, MD, ${ }^{a}$ on behalf of the PENPACT-1 (PENTA 9/PACTG 390) Study Team

aDivision of Infectious Diseases, Department of Pediatrics, Duke University Medical Center, Durham, North Carolina; ${ }^{b}$ Department of Epidemiology, Gillings School of Global Public Health, ${ }^{e}$ Division Infectious Diseases, Department of Medicine, School of Medicine, and gDepartment of Microbiology and Immunology, University of North Carolina at Chapel Hill, Chapel Hill, North Carolina; ${ }^{c}$ Division of Infectious Diseases, Department of Pediatrics, Children's Mercy Hospitals and Clinics, University of MissouriKansas City, Kansas City, Missouri; ${ }^{d}$ Center for Biostatistics in AIDS Research, Harvard School of Public Health, Boston, Massachusetts; IInfections Group, Medical Research Council Clinical Trials Unit, hInfectious Diseases and Microbiology Unit, Institute of Child Health, and IInstitute of Child Health and COMPLEX, University College London, London, United Kingdom; jDivision of Pediatric Infectious Disease, Department of Pediatrics, Seattle Children's Hospital, University of Washington, Seattle, Washington; and kSection of Pediatrics, Imperial College London, London, United Kingdom

KEY WORDS

child, HIV, immunologic, reconstitution, treatment failure

\section{ABBREVIATIONS}

CD4\% - CD4 percentage

CDC-Centers for Disease Control and Prevention

$\mathrm{Cl}$-confidence interval

DHHS-Department of Health and Human Services

HAART—highly active antiretroviral therapy

LTFU-loss to follow-up

RCT—randomized controlled trial

WHO-World Health Organization

(Continued on last page) 
Determining optimal timing for initiation of highly active antiretroviral therapy (HAART) in children infected with HIV remains a challenge. Globally in 2012, 3.3 million children were living with HIV, and 210000 children died due to AIDS. ${ }^{1}$ Although HAART has improved long-term survival, ${ }^{2}$ only $34 \%$ of eligible children currently receive treatment. ${ }^{1}$ Treatment guidelines must consider public health implications for not only disease progression,, 3 but also long-term complications of drug toxicities, ${ }^{4}$ inadequate adherence, ${ }^{5-7}$ resistance mutations, ${ }^{5}$ and cost-effectiveness. For HIV-infected infants, immediate HAART initiation is clearly needed, given its strong survival benefit, 8,9 improved neurodevelopmental outcomes, ${ }^{10}$ faster growth recovery, ${ }^{11}$ and the population's high mortality. ${ }^{12,13}$ However, for HIV-infected children presenting outside of infancy with minimal HIVrelated symptoms, the clinical benefits of early HAART initiation are unclear. ${ }^{14,15}$ Quantifying immunologic benefits of treatment initiation at different CD4 percentage (CD4\%) and age thresholds may inform public health decisions regarding optimal HAART initiation timing. Population-level immunologic effects of HAART initiation at different CD4\% and age combinations have been poorly quantified because most previous studies have only assessed associations. HIV-infected children who initiate HAART at lower CD4\% reach lower peak CD4 levels, ${ }^{4,16-24}$ perhaps from persistent effects of chronic immune activation. 25,26 HAART initiation at younger ages is associated with better immunologic recovery. ${ }^{17-20,24,27,28}$ Some Iongitudinal studies have quantified long-term CD4 trajectories on HAART based on pretreatment CD4 and age, allowing predictions that are child-specific. ${ }^{24,29}$ However, projected immunologic impacts at population levels have not been established.

Our aim was to quantify populationlevel impacts of HAART initiation at different CD4\% and age thresholds on CD4\% recovery. Our primary outcome was the proportion of immunosuppressed children ever achieving a normal CD4\% ( $\geq 10$ th percentile for age ${ }^{30}$ ) within 4 years of HAART initiation. Secondary outcomes were CD4\% at 4 years after HAART initiation and the proportion of children with a normal CD $4 \%$ at 4 years. The proportion of immunosuppressed children ever having a normal CD4\% within 4 years of HAART initiation reflects biological capacity for CD4\% reconstitution. The CD $4 \%$ and proportion of children normal at 4 years reflect outcomes inclusive of initial CD4\% recovery, potential immunologic failure, and possible immune restoration on a subsequent regimen.

\section{METHODS}

\section{Participants}

PENPACT-1 (Pediatric AIDS Clinical Trials Group 390/Paediatric European Network for Treatment of AIDS 9) ${ }^{31}$ was an international, multicenter, phase $2 / 3$, randomized, open-label, 2-by-2 factorial trial enrolling HIV-1-infected children (aged $>30$ days to $<18$ years) in Europe, North America, and South America between September 25, 2002, and September 7, 2005. Eligible children had not been treated with antiretrovirals or only received antiretrovirals to reduce motherto-child transmission (excluding singledose nevirapine) for $<56$ days and met local indications for HAART.

\section{Procedures}

At entry, children were randomly assigned (1:1) in 2-by-2 factorial design: (1) to start HAART with 2 nucleoside reverse transcriptase inhibitors plus either a protease inhibitor or nonnucleoside reverse transcriptase inhibitor and (2) to switch from first-line to second-line HAART at viral load thresholds of either 1000 copies $/ \mathrm{mL}$ or 30000 copies $/ \mathrm{mL}$. CD4\% and HIV RNA viral loads were measured at randomization (baseline, week 0); weeks 2, 4, 8, 12, 16, 24; and then every 12 weeks until the last enrollee reached 4 years of follow-up (August 31, 2009). Full study details are described elsewhere. ${ }^{31}$

Because previous PENPACT-1 analyses found no significant differences among randomized arms, ${ }^{31}$ we pooled participants across arms. To minimize confounding from unknown duration of infection, analyses were restricted to participants who were infected vertically.

For the primary outcome (CD4\% recovery within 4 years), data from vertically infected children with at least "mild" immunosuppression at baseline by World Health Organization (WHO) Immunologic Classification ${ }^{32}$ and CD4\% $<10$ th percentile for age ${ }^{30}$ were analyzed to determine the proportion of children who improved to normal CD4\% ( $\geq 10$ th percentile for age ${ }^{30}$ ) at any time within 4 years of follow-up. For secondary outcomes, data from all vertically infected children, regardless of baseline immune status, were analyzed for outcomes at 4 years after HAART initiation: CD4\% and proportion of children with normal CD4\% (see definitions in the next section).

\section{Definitions}

To account for age-related variability of CD4\%, we defined normal CD4\% recovery based on data from healthy, urban-dwelling, pediatric patients in the United States. ${ }^{30}$ For the primary outcome, recovery to normal was defined as 2 consecutive CD4\% measurements $\geq 10$ th percentile-for-age. Time of recovery was defined as the first of these CD4\% measurements. Participants lost to follow-up without recovery were censored in Kaplan-Meier analyses and counted as failures in regression analyses.

For secondary outcomes, CD4\% at 4 years was defined as the mean of CD $4 \%$ measurements at weeks 192 and 204. At week 192, all participants were $\geq 3$ 
years old, and CD4\% 10th percentilefor-age after 3 years old ranges between $28 \%$ to $31 \%$ without a consistent age-related trend. Thus, the definition of normal CD4\% at 4 years was simplified to be mean CD4\% $\geq 30 \%$.30,33 Participants missing 4-year CD4\% measurements were excluded from secondary outcome analyses.

Baseline CD4\% was categorized according to a modified version of the WHO Immunologic Classification for HIV-Associated Immunodeficiency. ${ }^{32}$ As this classification switches to CD4 cell counts after age 5 years, we used the following immunodeficiency (CD4\%) categories for subjects $\geq 5$ years (same as ages 3 to $<5$ years; see also the Centers for Disease Control and Prevention [CDC] HIV infection classification systems 34,35$)$ : "none/not significant" $>25 \%$, "mild" $20 \%$ to $25 \%$, "advanced" 15 to $<20 \%$, and "severe" $<15 \%$.

\section{Statistical Analysis}

Bivariate categorical analyses were performed by using Fisher's exact test. Continuous variables were analyzed by using linear regression. Trend linearity was assessed by using polynomial expansion and restricted quadratic splines with knots between quintiles.

Recovery to normal CD4\% within 4 years was analyzed by Kaplan-Meier methods with log-rank statistics and modified Poisson regression on an additive scale with Huber-White variance estimators (additive Poisson). ${ }^{36,37}$ CD4\% at 4 years was analyzed by using multivariable linear regression while having normal $\mathrm{CD} 4 \%$ at 4 years used additive Poisson regression. Models were constructed by using published literature and hypothesis-driven a priori assumptions to guide statistical assumptions, 38,39 then reduced by backward elimination using $P<.15$ and $>10 \%$ change-inestimate criteria. Models estimating baseline CD4\% main effects were adjusted for age, gender, and race. Models estimating age main effects were adjusted for gender and race. Interactions between immunologic classification and age were assessed and retained in models if $P<.15$. Hypothesis tests in Poisson regression used score statistics; linear regression used likelihood ratio tests. Statistical significance was defined as 2-sided $P<.05$.

Models were not adjusted for adherence or viral failure because both variables are on the causal pathway to CD4\% recovery. ${ }^{38}$ Adjustment for adherence or viral failure would control for information unavailable to clinicians when making decisions about treatment initiation and would add bias to estimates. ${ }^{40}$ However, we evaluated viral failure to assess the degree to which immunologic outcomes may be explained by poor viral control. Viral failure was defined as (1) failure to suppress HIV RNA viral load to $\leq 400$ copies $/ \mathrm{mL}$ by week 24 of HAART or (2) after initial viral suppression, viral load $>400$ copies $/ \mathrm{mL}$ for 2 consecutive measurements, the first occurring by week 192. Analyses used Cox models for testing associations and stratified proportional hazards models ${ }^{41}$ to estimate adjusted KaplanMeier failure probabilities. CD4\% main effect estimates were adjusted for age, continent, and baseline viral load. Age main effect estimates were adjusted for continent.

A loss to follow-up (LTFU) analysis evaluated bivariate relationships between baseline characteristics and missing CD4\% values at 4 years. To assess the potential influence of LTFU on results, sensitivity analyses corrected CD4\% outcomes at 4 years for LTFU by using a method similar to direct standardization (inverse-probability weighting methods). ${ }^{42}$

Statistical analyses used SAS version 9.3 (Cary, NC). This study is registered with International Standard Randomised Controlled Trial Number Register (ISRCTN73318385). The study protocol was deemed exempt by institutional review boards at Duke University and University of North Carolina.

\section{RESULTS}

\section{Baseline Characteristics and Overall Estimates}

PENPACT-1 enrolled 266 children infected with HIV-1 from 68 centers in 13 countries in Europe, North America, and South America; 263 were included in the main trial analysis. For analysis of CD4\% recovery within 4 years, 162 participants with baseline immunosuppression were included, and 209 qualified for analyses of CD4\% status at 4 years (Supplemental Fig 4). The baseline characteristics of all 209 vertically infected participants are shown in Table 1. At baseline, WHO-staged CD4\% was associated with age, race, and gender; marginally associated with continent and CDC clinical stage; and not associated with growth parameters (weight-forage $z$ score, height-for-age $z$ score, and BMl-for-age $z$ score) or baseline viral load. Age at HAART initiation was associated with race, continent, growth parameters, baseline viral load, and baseline CD4\% but not associated with gender or CDC clinical stage.

Eighty-seven percent (182 of 209) of participants had follow-up CD4\% measurements at 4 years. LTFU was only associated with continent (Europe 5\%, North America 27\%, South America 10\%; $P<.001$ ). Correcting for LTFU did not meaningfully alter study results (data not shown).

Of 162 children with baseline immunosuppression, the estimated probability of achieving a normal CD4\% within 4 years was $72 \%$ (95\% confidence interval [CI]: $64 \%$ to $78 \%$ ); mean CD4\% at 4 years was 30.9 (95\% Cl: 29.5 to 32.3 ); $56 \%$ of participants ( $95 \% \mathrm{Cl}: 48 \%$ to $64 \%$ ) had normal CD $4 \%$ at 4 years. 0 f 209 children with any baseline immune status, mean CD4\% at 4 years was 32.8 ( $95 \% \mathrm{Cl}: 31.5$ to 34.2), with $64 \%$ (95\% Cl: $57 \%$ to $71 \%$ ) of children having normal CD4\% at 4 years. 
TABLE 1 Characteristics of Children According to WHO Staged CD4\% and Age at HAART Initiation

\begin{tabular}{|c|c|c|c|c|c|c|c|c|}
\hline \multirow[t]{2}{*}{ Variable } & \multicolumn{6}{|c|}{$\begin{array}{l}\text { WHO Immunologic Classification for HIV-Associated Immunodeficiency } \\
\text { at HAART Initiation }\end{array}$} & \multicolumn{2}{|c|}{$\begin{array}{l}\text { Age (y) at HAART } \\
\text { Initiation }\end{array}$} \\
\hline & Severe & Advanced & Mild & None & Total & $P^{\mathrm{a}}$ & Mean (SD) & $P$ \\
\hline$n$ & 91 & 40 & 34 & 44 & 209 & & & \\
\hline \multicolumn{9}{|l|}{ Age, $n(\%)$} \\
\hline $0-4$ y & $41(41)$ & $13(13)$ & $18(18)$ & $27(27)$ & 99 & \multirow[t]{3}{*}{.07} & $2.0(1.5)$ & \multirow[t]{4}{*}{$\mathrm{N} / \mathrm{A}$} \\
\hline $5-9$ y & 27 (39) & $18(26)$ & $12(17)$ & $13(19)$ & 70 & & $8.0(2.2)$ & \\
\hline 10-17 y & $23(58)$ & $9(23)$ & $4(10)$ & $4(10)$ & 40 & & $15.1(1.5)$ & \\
\hline Age, y, M (SD) & $6.3(4.7)$ & $7.0(4.7)$ & $4.9(4.0)$ & $4.2(3.8)$ & $5.8(4.5)$ & .01 & $5.8(4.5)$ & \\
\hline \multicolumn{9}{|l|}{ Gender } \\
\hline Female, $n(\%)$ & $35(34)$ & $18(17)$ & $25(24)$ & $25(24)$ & 103 & \multirow[t]{2}{*}{.003} & $5.6(4.5)$ & \multirow[t]{2}{*}{.59} \\
\hline Male & $56(53)$ & $22(21)$ & $9(8)$ & $19(18)$ & 106 & & $6.0(4.6)$ & \\
\hline \multicolumn{9}{|l|}{ Race, $n(\%)$} \\
\hline Black, non-Hispanic & $48(42)$ & $26(23)$ & $22(19)$ & $18(16)$ & 114 & \multirow[t]{3}{*}{.04} & $6.8(4.8)$ & \multirow[t]{3}{*}{$<.001$} \\
\hline White, non-Hispanic & $12(34)$ & $5(14)$ & $3(9)$ & $15(43)$ & 35 & & $3.2(3.3)$ & \\
\hline Hispanic/other & $31(52)$ & $9(15)$ & $9(15)$ & $11(18)$ & 60 & & $5.5(4.0)$ & \\
\hline \multicolumn{9}{|l|}{ Continent, $n$ (\%) } \\
\hline Europe & $40(43)$ & $26(28)$ & $13(14)$ & $15(16)$ & 94 & \multirow[t]{3}{*}{.05} & $5.0(3.9)$ & \multirow[t]{3}{*}{.002} \\
\hline North America & $30(48)$ & $10(16)$ & $9(14)$ & $14(22)$ & 63 & & $7.4(5.5)$ & \\
\hline South America & $21(40)$ & $4(8)$ & $12(23)$ & $15(29)$ & 52 & & $5.2(3.6)$ & \\
\hline \multicolumn{9}{|l|}{ CDC clinical stage, $n(\%)$} \\
\hline $\mathrm{N}$ or $\mathrm{A}$ & $41(37)$ & $24(22)$ & $24(22)$ & $22(20)$ & 111 & \multirow[t]{2}{*}{.06} & $5.9(4.8)$ & \multirow[t]{2}{*}{.78} \\
\hline B or C & $50(51)$ & $16(16)$ & $10(10)$ & $22(22)$ & 98 & & $5.7(4.1)$ & \\
\hline \multicolumn{9}{|l|}{ Treatment regimen, $n$ (\%) } \\
\hline NNRTI & $46(43)$ & $16(15)$ & $22(21)$ & $22(21)$ & 106 & \multirow[t]{2}{*}{$\mathrm{N} / \mathrm{A}^{\mathrm{b}}$} & $5.3(4.1)$ & \multirow[t]{2}{*}{$N / A^{b}$} \\
\hline $\mathrm{PI}$ & $45(44)$ & $24(23)$ & $12(12)$ & $22(21)$ & 103 & & $6.3(4.9)$ & \\
\hline \multicolumn{9}{|l|}{ Switching threshold, $n$ (\%) } \\
\hline 1000 copies/mL & $46(44)$ & $19(18)$ & $14(13)$ & $25(24)$ & 104 & \multirow[t]{2}{*}{$N / A^{b}$} & $5.6(4.5)$ & \multirow[t]{2}{*}{$N / A^{b}$} \\
\hline 30000 copies/mL & $45(43)$ & $21(20)$ & $20(19)$ & $19(18)$ & 105 & & $6.0(4.5)$ & \\
\hline \multicolumn{9}{|l|}{ z score, M (SD) } \\
\hline Weight for age & $-0.6(1.6)$ & $-0.8(1.2)$ & $-0.6(1.1)$ & $-0.7(1.5)$ & $-0.7(1.4)$ & .81 & $r=0.32$ & $<.001$ \\
\hline Height for age & $-1.0(1.4)$ & $-1.0(0.8)$ & $-0.8(1.1)$ & $-0.8(1.3)$ & $-0.9(1.2)$ & .81 & $r=0.16$ & .02 \\
\hline BMI & $-0.0(1.4)$ & $-0.4(1.5)$ & $-0.2(1.2)$ & $-0.2(1.3)$ & $-0.2(1.4)$ & .59 & $r=0.29$ & $<.001$ \\
\hline Baseline viral load $\log _{10}$ copies/mL, M (SD) & $5.2(0.9)$ & $5.1(0.8)$ & $4.8(1.0)$ & $5.0(0.8)$ & $5.1(0.9)$ & .31 & $r=-0.54$ & $<.001$ \\
\hline Baseline CD4\%, M (SD) & $10.2(5.7)$ & $18.5(3.8)$ & $25.4(4.9)$ & $35.6(7.1)$ & $19.6(11.4)$ & $\mathrm{N} / \mathrm{A}$ & $r=-0.44$ & $<.001$ \\
\hline
\end{tabular}

N/A, not applicable; NNRTI, nonnucleoside reverse transcriptase inhibitor; PI, protease inhibitor.

a Comparisons used Fisher's exact test for categorical variables and linear regression for continuous variables

b $P$ values are not reported because any differences were determined by randomization.

\section{Baseline CD4\%}

CD4\% recovery within 4 years was significantly associated with WHO-staged baseline CD4\% (Kaplan-Meier, $P<.001$; Fig 1). In regression models, baseline CD4\% was significantly associated with all three 4-year CD4\% outcomes: proportion of immune suppressed children ever recovering a normal CD4\% within 4 years (unadjusted $P<.001$, adjusted $P<.001$; Fig 1); CD4\% at 4 years (unadjusted $P<$ .001 , adjusted $P<.001$; Table 2); and proportion of children normal at 4 years (unadjusted $P<.001$, adjusted $P<.001$; Table 2). Compared with WHO "severe" immunosuppression, each increase in baseline CD4\% category had an increasing trend in proportion of children ever nor- mal within 4 years (Fig 1), CD4\% at 4 years (Table 2), and proportion of children normal at 4 years (Table 2).

\section{Age at HAART Initiation}

CD4\% recovery within 4 years was significantly associated with age (KaplanMeier, $P<.001$; Fig 2). The association between age and CD4\% recovery was approximately linear (by significance testing) for all three 4-year CD4\% outcomes (Fig 3A-3C). In multivariable linear regressions adjusting for gender and race, each 5-year increase in age at HAART initiation had an estimated (1) reduction of $19 \%$ in proportion of children ever having a normal CD4\% within 4 years (95\% Cl: $11 \%$ to $27 \% ; P<.001$ ),
(2) decrease in CD4\% at 4 years of 2.9 percentage points ( $95 \% \mathrm{Cl}: 1.4 \%$ to $4.3 \%$; $P<.001$ ), and (3) reduction in proportion of children with a normal $\mathrm{CD} 4 \%$ at 4 years of $7 \%$ (95\% $\mathrm{Cl}:-1 \%$ to $16 \% ; P=.08)$.

\section{Combined Effects of Baseline CD4\% and Age}

The interaction between baseline CD4\% and age on the probability of ever recovering a normal CD4\% within 4 years was statistically significant (unadjusted $P=.009$, adjusted $P=.02$; Table 3 ). This interaction was synergistic: with increasing age, baseline CD4\% had a stronger effect on the capacity to recover a normal CD4\% within 4 years. However, interactions 


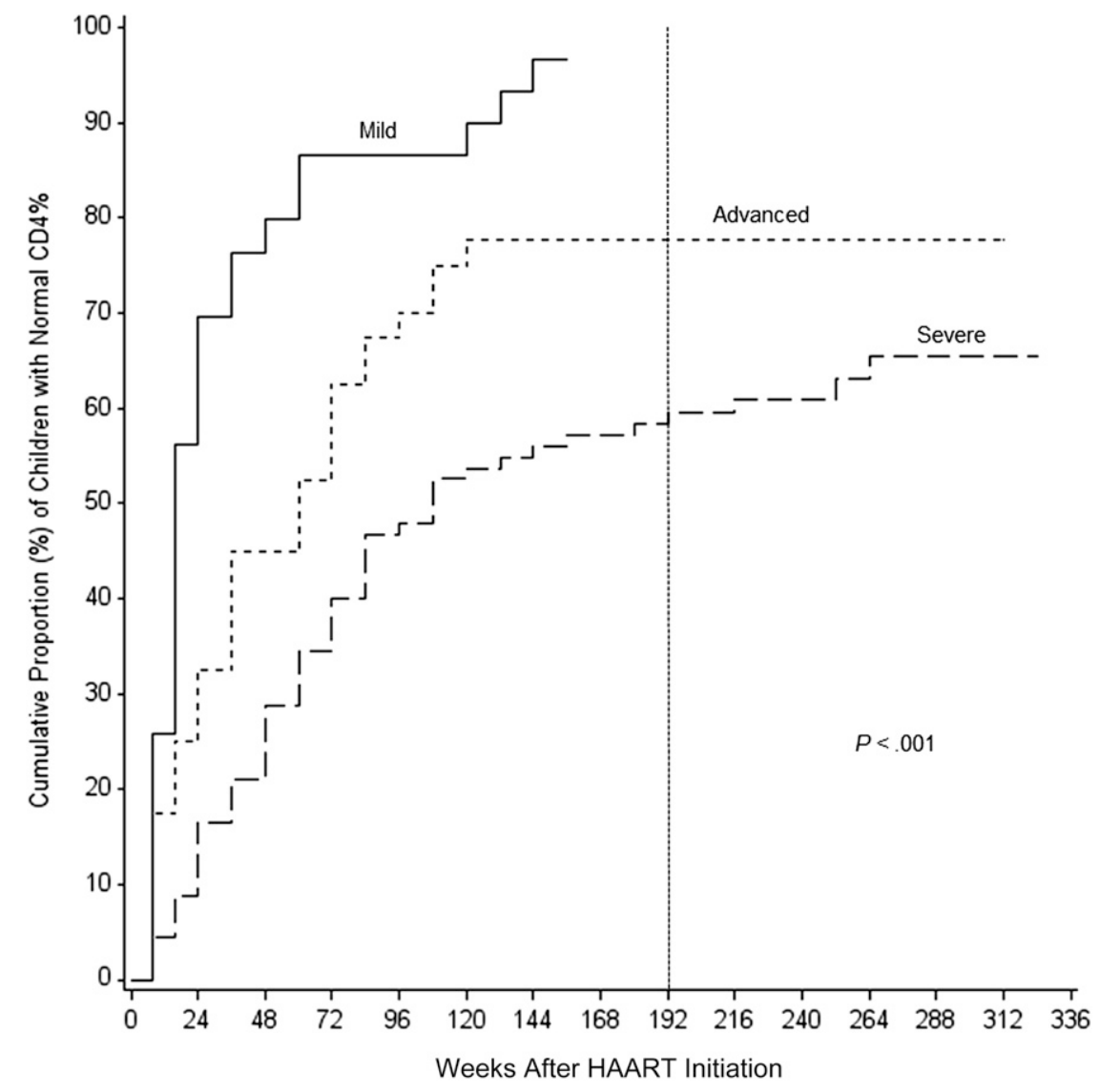

\begin{tabular}{|cccc|}
\hline $\begin{array}{c}\text { Baseline WHO } \\
\text { Immunodeficiency } \\
\text { Classification }\end{array}$ & $n$ & $\begin{array}{c}\text { Proportion Ever Normal } \\
\text { Within } 4 \text { years } \\
\%(95 \% \mathrm{Cl})\end{array}$ & $\begin{array}{c}\text { Difference vs Severe } \\
\%(95 \% \mathrm{Cl})\end{array}$ \\
\hline Mild & 31 & $97 \%(85 \%$ to $99 \%)$ & $36 \%(22 \%$ to $49 \%)$ \\
Advanced & 40 & $78 \%(62 \%$ to $87 \%)$ & $21 \%(6 \%$ to $36 \%)$ \\
Severe & 91 & $60 \%(48 \%$ to $68 \%)$ & Reference \\
\hline $\begin{array}{l}\text { a Kaplan-Meier estimates, unadjusted. } \\
\text { b Modified Poisson regression estimates, adjusted for age, sex, race, and interaction between WHO } \\
\text { Immunological Classification and age (at mean age } 6.3 \text { years). }\end{array}$ \\
\hline
\end{tabular}

\section{FIGURE 1}

Cumulative proportion of children with CD4\% recovery to normal versus weeks after HAART initiation, by baseline WHO Immunodeficiency Classification ("mild," "advanced," "severe"). Primary outcome is CD $4 \% \geq 10$ th percentile for age by week 192 , marked by vertical dashed line. $P$ value is from log-rank statistic.

between baseline CD4\% and age were not significant for CD4\% at 4 years (unadjusted $P=.91$; adjusted $P=.91$ ) or the proportion of children with normal $\mathrm{CD} 4 \%$ at 4 years (unadjusted $P=.50$, adjusted $P=.59$; Table 4).

A model including baseline CD4\%, age, gender, race, and a baseline CD4\%-byage interaction predicted $>90 \%$ probability of CD4\% recovery within 4 years when initiating HAART with "mild" immunosuppression at any age or with
4 years. Twenty-nine (14\%) failed to suppress to $\leq 400$ copies $/ \mathrm{mL}$ by week 24 , and 53 (25\%) suppressed but experienced viral rebound to $>400$ copies $/ \mathrm{mL}$. One participant $(0.5 \%)$ was LTFU before week 24. Viral failure was not associated (Cox model, unadjusted $P=.36$, adjusted $P=.23)$ with baseline immunodeficiency classification (adjusted Kaplan-Meier failure probability: "none" $32 \%$, "mild" $54 \%$, "advanced" 44\%, "severe" 40\%). Viral failure and age had a bimodal relationship (Cox model, unadjusted $P<.001$, adjusted $P<.001$ ) with peaks in infancy and adolescence (adjusted Kaplan-Meier failure probability: 0 to $<1$ year $56 \%, 1$ to $<3$ years $34 \%, 3$ to $<5$ years $32 \%, 5$ to $<8$ years $24 \%$, 8 to $<13$ years $38 \%, 13$ to $<18$ years $63 \%$; Fig $3 \mathrm{D}$ ).

\section{DISCUSSION}

On the basis of these PENPACT-1 results, initiating HAART at healthier immunologic stages and younger ages may have profound impacts on immunologic recovery. We suggest that HAART initiation when children first have "mild" immunosuppression would result in almost all children experiencing full CD4\% recovery. Similarly, HAART at younger ages would yield high probabilities of immune recovery and may blunt negative effects of "severe" immunosuppression. Although not all children maintained immune recovery (demonstrated by more attenuated immunologic benefits at 4 years) most CD4\% outcomes at 4 years were still improved in children starting HAART at healthier CD4 levels and younger ages. Our results quantify the magnitude of these effects on immunologic outcomes to help inform public health planning.

The PENPACT-1 data align with US Department of Health and Human Services (DHHS) pediatric HIV treatment guidelines.3,43 The DHHS recommends initiating HAART in all HIV-infected infants and any HIV-infected children with AIDS or most CDC Clinical Category B or C conditions; confirmed plasma HIV RNA levels 


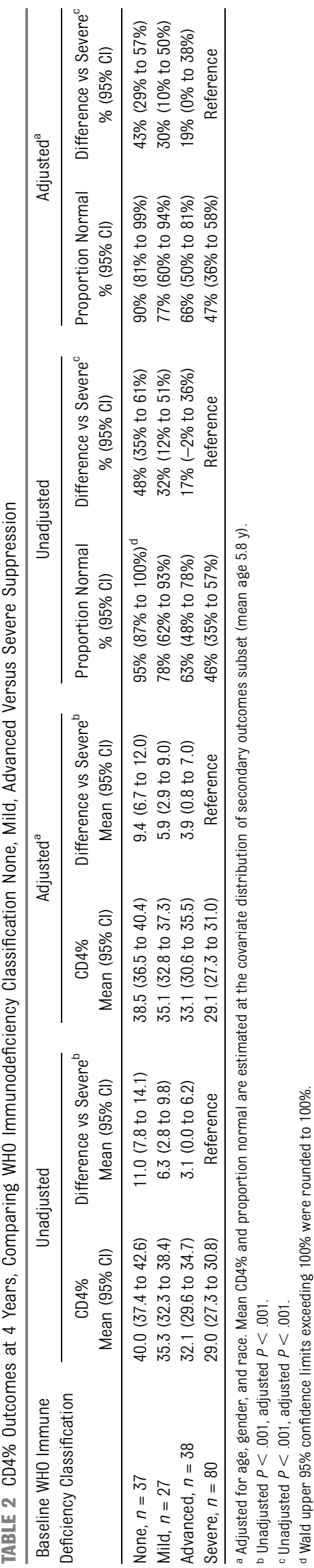

$>100000$ copies $/ \mathrm{mL}$; aged 1 to $<3$ years with CD4 cell count $<1000$ cells $/ \mathrm{mm}^{3}$ or $\mathrm{CD} 4 \%<25 \%$; ages 3 to $<5$ years with CD 4 count $<750$ cells $/ \mathrm{mm}^{3}$ or $<25 \%$; or age $\geq 5$ years with CD 4 count $<500$ cells $/ \mathrm{mm}^{3}$ (with considerations for treating at higher CD4 levels). ${ }^{33}$ DHHS-recommended CD4\% and age treatment thresholds correspond to WHO immunodeficiency classifications of "advanced" for ages 1 to $<3$ years and "mild" for all age categories $\geq 3$ years. If all children aged 1 to $<13$ years in PENPACT-1 had initiated HAART immediately after reaching DHHS-recommended CD4\% and age treatment thresholds, we estimate $>90 \%$ of these children would have experienced $\mathrm{CD} 4 \%$ recovery to normal within 4 years, and $>80 \%$ would have had a normal $\mathrm{CD} 4 \%$ at 4 years.

Evidence supporting early treatment is strongest in infants. A randomized controlled trial (RCT) of HIV-infected infants in South Africa found that, compared with delaying treatment until infants met prespecified clinical or CD4\% criteria, immediate HAART initiation reduced early infant mortality by $76 \%$ and HIV progression by $75 \% .{ }^{8}$ Infants with immediate treatment had better gross motor and general neurodevelopmental scores, ${ }^{10}$ and treatment $<6$ months old may have faster improvements in weight-forage and head circumference-for-age $z$ scores. ${ }^{11}$ A Cochrane review on effectiveness of HAART in HIV-infected children $<3$ years old concluded that immediate HAART reduces morbidity and mortality in infants, but clinical benefits of universal treatment initiation in children aged 1 to 3 years remain unclear. $^{9}$

Evidence for early treatment in children $\geq 1$ year old is less compelling. An RCT in Thailand and Cambodia of HIVinfected children aged 1 to 12 years with CD4\% $15 \%$ to $24 \%$ found that immediate versus delayed HAART resulted in similar 144-week AIDS-free survival (98.7\% vs $97.9 \%)$ but improved height $z$ scores and higher CD4\% (33.2\% vs 24.8\%). ${ }^{15}$ Neurodevelopmental scores were no different across arms. ${ }^{14}$ Links among pretreatment CD4, age, and long-term CD4 recovery have been established in literature. ${ }^{17-20,24}$ However, our estimates allow the reader to quantify population-level immunologic benefits of early versus delayed treatment at combinations of CD4\% and age.

Adolescent recommendations are based primarily on adult data. ${ }^{44}$ Adult RCTs found decreased AIDS progression or death with HAART in patients with acute opportunistic illnesses, ${ }^{45} \mathrm{CD} 4<200$ cells/ $\mathrm{mm}^{3,46}$ or CD4 200 to $<350$ cells $/ \mathrm{mm}^{3}{ }^{3}$ Adult cohort studies suggest that initiating HAART at CD4 counts 350 to 500 cells $/ \mathrm{mm}^{3}$ reduces HIV-related disease progression but have conflicting results at CD4 $>500$ cells $/ \mathrm{mm}^{3}{ }^{48-51}$ Adult data further support earlier treatment to enhance CD4 recovery ${ }^{52}$ and prevent HIV sexual transmission. ${ }^{53}$ Consequently, DHHS guidelines recommend universal HAART in all HIV-infected adults and adolescents. ${ }^{44}$

From our PENPACT-1 results, we are concerned by the poor outcomes in older children and adolescents, particularly those with poor baseline immunologic status. Biologically, we expected relationships between CD4\% recovery and age to plateau because thymic potential stabilizes as children approach adult immune maturity. ${ }^{24,27,28}$ Instead, CD4\% outcomes declined through adolescence, likely from increasing adherence struggles and viral failure. ${ }^{7,54}$ Consistent with child-specific predictions, ${ }^{24}$ older children and adolescents may benefit most dramatically from earlier HAART initiation (complementary to strategies for better case finding, adherence, or therapeutic approaches for improving immunologic potential).

Immunologic benefits of earlier treatment should be weighed against potential 


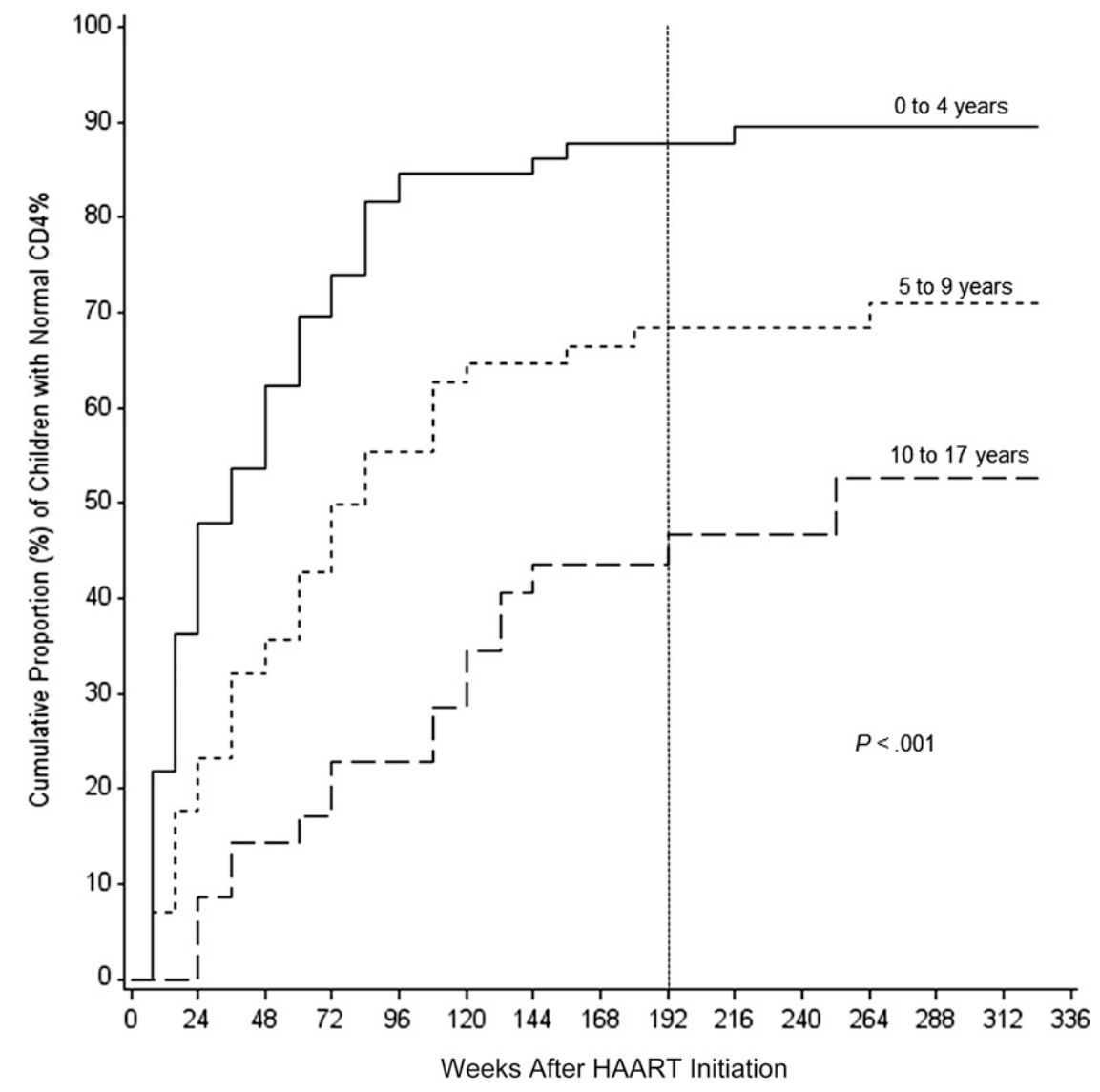

\begin{tabular}{|cccc|}
\hline $\begin{array}{c}\text { Age at HAART Initiation } \\
\text { (years) }\end{array}$ & $n$ & $\begin{array}{c}\text { Proportion Ever Normal } \\
\text { Within } 4 \text { years } \\
\%(95 \% \mathrm{Cl})\end{array}$ & $\begin{array}{c}\text { Difference vs Severe } \\
\%(95 \% \mathrm{Cl})\end{array}$ \\
\hline 0 to 4 & 69 & $88 \%(78 \%$ to $93 \%)$ & $42 \%(23 \%$ to $61 \%)$ \\
5 to 9 & 57 & $68 \%(54 \%$ to $78 \%)$ & $19 \%(-1 \%$ to $40 \%)$ \\
10 to 17 & 36 & $47 \%(28 \%$ to $61 \%)$ & Reference \\
\hline $\begin{array}{l}\text { s Kaplan-Meier estimates, unadjusted. } \\
\text { bModified Poisson regression estimates, adjusted for gender and race. }\end{array}$ & \\
\hline
\end{tabular}

\section{FIGURE 2}

Cumulative proportion of children with CD4\% recovery to normal versus weeks after HAART initiation, by age at HAART initiation (0-4, 5-9, 10-17 years). Primary outcome is CD4\% $\geq 10$ th percentile for age by week 192, marked by vertical dashed line. $P$ value is from log-rank statistic.

harms. In PENPACT-1, viral failure was worse at age extremes, consistent with studies finding poor viral suppression at younger ages 6,19 and myriad adherence difficulties in adolescents. ${ }^{7,54}$ For some children, immunologic recovery is transient, and starting HAART earlier may eventually lead to fewer treatment options. Fortunately, HAART initiation at higher CD4 counts may mitigate antiretroviral resistance at viral failure ${ }^{55}$ Still, diminishing immunologic benefits precluded more intricate model specification. Finally, analysis of potential sources of bias ${ }^{38}$ suggested possible unmeasured confounding from host immunology and HIV virulence, which were untestable in our data.

\section{CONCLUSIONS}

Earlier HAART initiation in children with vertically acquired HIV-1 substantially improves immunologic recovery within 4 years. Optimizing treatment timing by CD4\% and age may have significant long-term immunologic benefits. Older children and adolescents, in particular, may benefit from earlier treatment. Nevertheless, immunologic benefits diminished over time, and treatment decisions should weigh potential risks, including viral failure. Estimates of this kind allow immunologic benefits of alternative HAART initiation thresholds to be balanced against their clinical, social, and financial costs.

\section{ACKNOWLEDGMENTS}

\section{THE PENPACT-1 (PAEDIATRIC EUROPEAN NETWORK FOR TREATMENT OF AIDS [PENTA 9]/ PEDIATRIC AIDS CLINICAL TRIALS GROUP [PACTG 390]) STUDY TEAM}

\section{PENPACT-1 Protocol Team}

PACTG/International Maternal Pediatric Adolescent AIDS Clinical Trials Group (IMPAACT)/Eunice Kennedy Shriver National Institute of Child Health and Human Development (NICHD): P. Brouwers, D. Costello, E. Ferguson, S. Fiscus, J. Hodge, M. Hughes, C. Jennings, A. Melvin (Co-Chair), R. McKinney (Co-Chair), L. Mofenson, M. Warshaw, M.E. Smith, S. Spector, E. Stiehm, M. Toye, R. Yogev. PENTA: J.P. Aboulker, A. Babiker, H. Castro, A. Compagnucci, A. De Rossi, C. Giaquinto, J. Darbyshire, M. Debré, D.M. Gibb, L. Harper, L. Harrison, N. Klein, D. Pillay, Y. Saidi, G. Tudor-Williams (Co-Chair), A.S. Walker. 

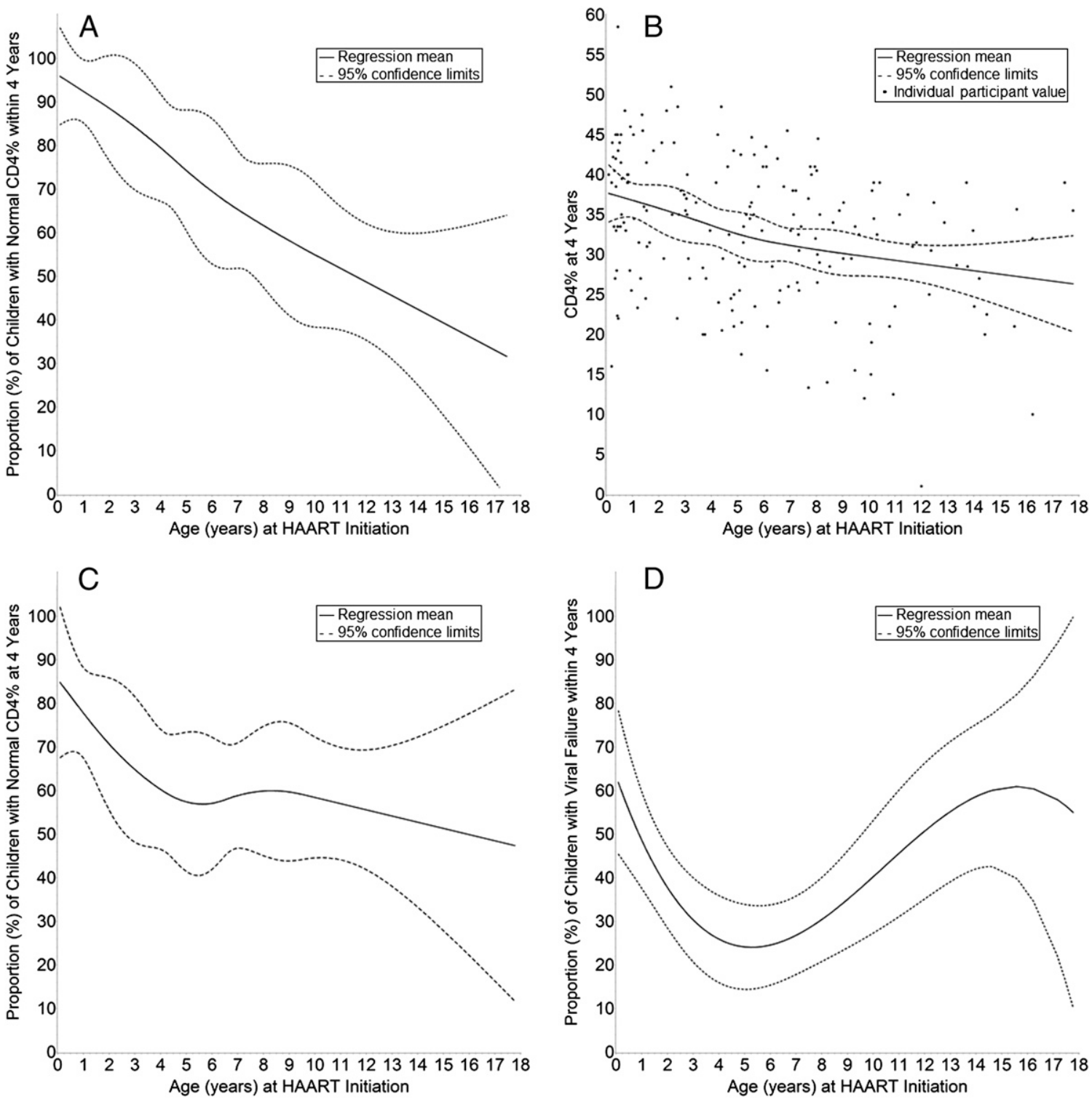

FIGURE 3

Relationship between age at HAART initiation and (A) proportion of children with normal CD4\% within 4 years, (B) CD4\% at 4 years, (C) proportion of children with normal CD4\% at 4 years, (D) proportion of children with viral failure within 4 years. Panels A, B, and C illustrate splines; panel D illustrates a cubic function

Data and Safety Monitoring Board: B. Brody, C. Hill, P. Lepage, J. Modlin, A. Poziak, M. Rein (Chair 2002-2003), M. Robb (Chair 2004-2009), T. Fleming, S. Vella, K.M. Kim.

\section{Clinical Sites $(\mathrm{L}=$ laboratory, $\mathbf{P}=$ pharmacy)}

Argentina: Hospital de Pediatria Dr J.P. Garrahan, Buenos Aires: R. Bologna, D. Mecikovsky, N. Pineda, L. Sen (L), A. Mangano (L), S. Marino (L), C. Galvez (L); Laboratorio Fundai: G. Deluchi (L).
Austria: Universitätsklinik für Kinder und Jugendheilkunde, Graz: B. Zöhrer, W. Zenz, E. Daghofer, K. Pfurtscheller, B. Pabst (L).

Bahamas: Princess Margaret Hospital: M.P. Gomez, P. McNeil, M. Jervis, I. Whyms, D. Kwolfe, S. Scott (P)

Brazil: University of São Paulo at Ribeirão Preto: M.M. Mussi-Pinhata, M.L. Issac, M.C. Cervi, B.V.M. Negrini, T.C. Matsubara, C.B.S.S. de Souza (L), J.C. Gabaldi (P); Institute of Pediatrics (IPPMG), Federal University of Rio de
Janeiro: R.H. Oliveira, M.C. Sapia, T. Abreu, L. Evangelista, A. Pala, I. Fernandes, I. Farias, M. de F. Melo (L), H. Carreira (P), L.M. Lira (P); Instituto de Infectologia Emilio Ribas, São Paolo: M. Della Negra, W. Queiroz, Y.C. Lian; D.P. Pacola; Fleury Laboratories; Federal University of Minas Gerais, Belo Horizonte: J. Pinto, F. Ferreira, F. Kakehasi, L. Martins, A. Diniz, V. Lobato, M. Diniz, C. Hill (L), S. Cleto (L), S. Costa (P), J. Romeiro (P)

France: Hôpital d'enfants Armand Trousseau, Paris: C. Dollfus, M.D. Tabone, 
TABLE 3 Projected Probabilities of Ever Recovering a Normal CD4\% Within 4 Years, by WH0 Immunodeficiency Classification and Age,

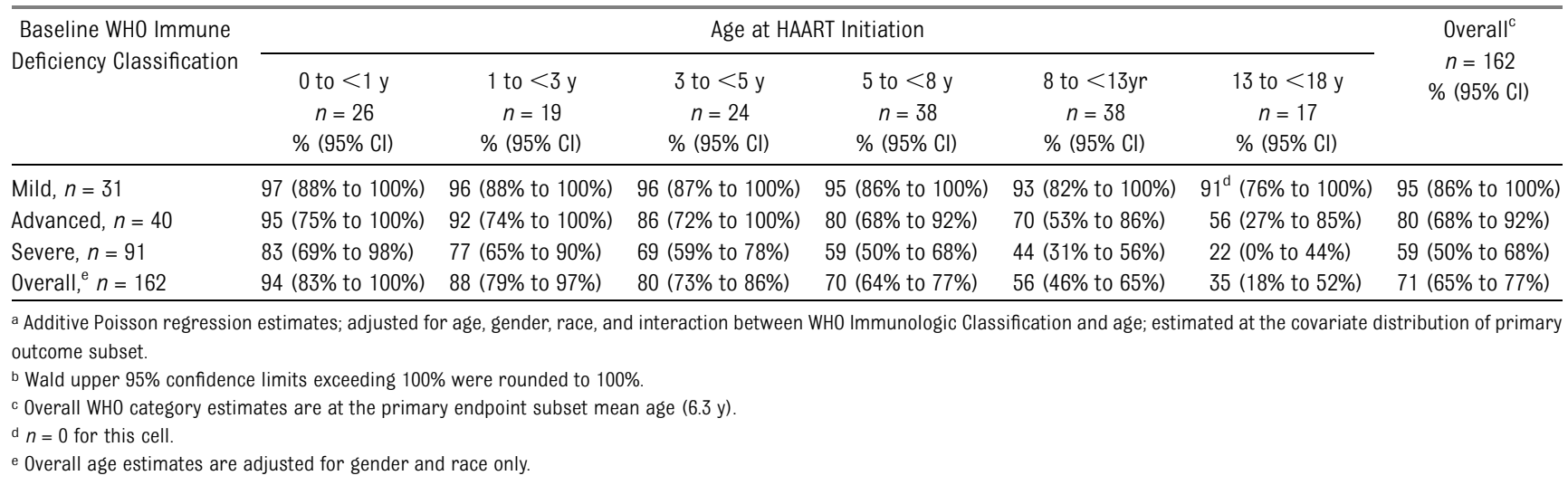

M.F. Courcoux, G. Vaudre, A. Dehée (L), A .Schnuriger (L), N. Le Gueyades (P), C. De Bortoli (P); CHU Hôtel Dieu, Nantes: F Méchinaud, V Reliquet, J. Arias (L), A. Rodallec (L), E. André (L), I. Falconi (P), A. Le Pelletier (P); Hôpital de l'Archet II, Nice, F. Monpoux, J. Cottalorda (L), S. Mellul (L); Hôpital Jean Verdier, Bondy: E. Lachassinne; Laboratoire de virologie-Hôpital Necker Enfants Malades, Paris: J. Galimand (L), C. Rouzioux (L), M.L. Chaix (L), Z. Benabadji (P), M. Pourrat (P); Hôpital Cochin Port-Royal-Saint Vincent de Paul, Paris: G. Firtion, D. Rivaux, M. Denon, N. Boudjoudi, F. Nganzali, A. Krivine (L), J.F. Méritet (L), G. Delommois (L), C. Norgeux (L), C. Guérin (P); Hôpital Louis Mourier, Colombes: C. Floch, L. Marty, H. Hichou (L), V. Tournier (P); Hôpital Robert Debré, Paris: A. Faye, I. Le Moal, M. Sellier (P), L. Dehache (P); Laboratoire de virologie, Hôpital Bichat Claude Bernard, Paris:
F. Damond (L), J. Leleu (L), D. Beniken (L), G. Alexandre-Castor (L).

Germany: Universitäts-Kinderklinik Düsseldorf: J. Neubert, T. Niehues, H.J. Laws, K. Huck, S. Gudowius, K. Siepermann, H. Loeffler, S. Bellert (L), A. Ortwin (L); Universitäts-Kinderkliniken, Munich: G. Notheis, U. Wintergerst, F. Hoffman, A. Werthmann, S. Seyboldt, L. Schneider, B. Bucholz; Charité-Medizische Fakultät der Humboldt-Universitätzu Berlin: C. Feiterna-Sperling, C. Peiser, R. Nickel, T. Schmitz, T. Piening, C. Müller (L); Kinder und Jugendklinik, Universität Rostock: G. Warncke, M. Wigger, R. Neubauer.

Ireland: Our Lady's Children's Hospital Crumlin, Dublin: K. Butler, A.L. Chong, T. Boulger, A. Menon, M. O'Connell, L. Barrett, A. Rochford, M. Goode, E. Hayes, S. McDonagh, A. Walsh, A. Doyle, J. Fanning (P), M. O'Connor (P), M. Byrne (L), N. O'Sullivan (L), E. Hyland (L).
Italy: Clinica Pediatrica, Ospedale L. Sacco, Milan: V. Giacomet, A. Viganò, I. Colombo, D. Trabattoni (L), A. Berzi (L); Clinica Pediatrica, Università di Brescia: R. Badolato, F. Schumacher, V. Bennato, M. Brusati, A. Sorlini, E. Spinelli, M. Filisetti, C. Bertulli; Clinica Pediatrica, Università di Padova: 0. Rampon, C. Giaquinto, M. Zanchetta (L); Ospedale S. Chiara, Trento: A. Mazza, G. Stringari, G. Rossetti (L); Ospedale del Bambino Gesù, Rome: S. Bernardi, A. Martino, G. Castelli Gattinara, P. Palma, G. Pontrelli, H. Tchidjou, A. Furcas, C. Frillici, A. Mazzei, A. Zoccano (P), C. Concato (L).

Romania: Spitalul Clinic de Boli Infectioase Victor Babes, Bucharest: D Duiculescu, C Oprea, G Tardei (L), FAbaab (P); Institutul de Boli Infectioase Matei Bals, Bucharest: M Mardarescu, R Draghicenoiu, D Otelea (L), L Alecsandru (P); Clinic Municipal, Constanta: R Matusa, SRugina, M llie, Silvia Netescu (P). Clinical monitors: C Florea,

TABLE 4 Projected Probabilities of Having a Normal CD4\% at 4 Years, by WHO Immunodeficiency Classification and Age $\mathrm{e}^{\mathrm{a}, \mathrm{b}}$

\begin{tabular}{|c|c|c|c|c|c|c|c|}
\hline \multirow{2}{*}{$\begin{array}{l}\text { Baseline WHO Immune } \\
\text { Deficiency Classification }\end{array}$} & \multicolumn{6}{|c|}{ Age at HAART Initiation ${ }^{c}$} & \multirow{2}{*}{$\begin{array}{c}\text { Overall }^{\mathrm{C}} \\
n=182 \\
\%(95 \% \mathrm{Cl})\end{array}$} \\
\hline & $\begin{array}{c}0 \text { to }<1 \text { y } \\
n=35 \\
\%(95 \% \mathrm{Cl})\end{array}$ & $\begin{array}{c}1 \text { to }<3 \text { y } \\
n=25 \\
\%(95 \% \mathrm{Cl})\end{array}$ & $\begin{array}{c}3 \text { to }<5 \text { y } \\
n=25 \\
\%(95 \% \mathrm{Cl})\end{array}$ & $\begin{array}{c}5 \text { to }<8 \text { y } \\
n=45 \\
\%(95 \% \mathrm{Cl})\end{array}$ & $\begin{array}{c}8 \text { to }<13 \text { y } \\
n=38 \\
\%(95 \% \mathrm{Cl})\end{array}$ & $\begin{array}{c}13 \text { to }<18 \text { y } \\
n=14 \\
\%(95 \% \mathrm{Cl})\end{array}$ & \\
\hline None, $n=37$ & 99 (88\% to $100 \%)$ & 97 (87\% to $100 \%)$ & 93 (85\% to $100 \%)$ & 89 (80\% to $98 \%)$ & $83(70 \%$ to $96 \%)$ & $74(53 \%$ to $96 \%)$ & $90(81 \%$ to $99 \%)$ \\
\hline Mild, $n=27$ & $86(67 \%$ to $100 \%)$ & $83(65 \%$ to $100 \%)$ & $80(63 \%$ to $97 \%)$ & 76 (59\% to $93 \%)$ & $70(51 \%$ to $89 \%)$ & $61^{d}(36 \%$ to $86 \%)$ & $77(60 \%$ to $94 \%)$ \\
\hline Advanced, $n=38$ & $74(55 \%$ to $94 \%)$ & 72 (54\% to $90 \%)$ & $69(52 \%$ to $85 \%)$ & $65(49 \%$ to $80 \%)$ & $59(42 \%$ to $75 \%)$ & $50(28 \%$ to $71 \%)$ & $66(50 \%$ to $81 \%)$ \\
\hline Severe, $n=80$ & $56(41 \%$ to $70 \%)$ & $53(41 \%$ to $66 \%)$ & 50 (39\% to $61 \%)$ & $46(35 \%$ to $57 \%)$ & $40(27 \%$ to $53 \%)$ & $31(11 \%$ to $52 \%)$ & 47 (36\% to $58 \%)$ \\
\hline Overall, ${ }^{\mathrm{e}} n=182$ & $75(64 \%$ to $85 \%)$ & $72(63 \%$ to $81 \%)$ & $68(60 \%$ to $75 \%)$ & $63(56 \%$ to $70 \%)$ & $56(45 \%$ to $66 \%)$ & $45(27 \%$ to $63 \%)$ & $64(58 \%$ to $71 \%)$ \\
\hline
\end{tabular}

a Additive Poisson regression estimates; adjusted for age, gender, and race; estimated at covariate distribution of secondary outcomes subset.

b Wald upper $95 \%$ confidence limits exceeding $100 \%$ were rounded to $100 \%$.

${ }^{c}$ Overall WHO category estimates are at the secondary end point subset mean age (5.8 y).

d $n=0$ for this cell.

e Overall age estimates are adjusted for gender and race only. 
E Voicu, D Poalelungi, C Belmega, LVladau, A Chiriac.

Spain: Hospital Materno-Infantil 12 de Octubre, Madrid: J.T. Ramos Amador, M.I. Gonzalez Tomé, P. Rojo Conejo, M. Fernandez, R. Delgado Garcia (L), J.M. Ferrari (P); Institute de Salud Carlos III, Madrid: M. Garcia Lopez, M.J. Mellado Peña, P. Martin Fontelos, I. Jimenez Nacher (P); Biobanco Gregorio Marañon, Madrid: M.A. Muñoz Fernandez (L), J.L. Jimenez (L), A. García Torre (L); clinical monitors: M. Penin, R. Pineiro Perez, I. Garcia Mellado.

United Kingdom: Bristol Royal Children's Hospital: A. Finn, M. LaJeunesse, E. Hutchison, J. Usher (L), L. Ball (P), M. Dunn (P); St George's Healthcare NHS Trust, London: M. Sharland, K. Doerholt, S. Storey, S. Donaghy, R. Chakraborty, C. Wells (P), K. Buckberry (P), P. Rice (P); University Hospital of North Staffordshire: P. McMaster, P. Butler, C. Farmer (L), J. Shenton (P), H. Haley (P), J. Orendi (L), University Hospital Lewisham: J. Stroobant, L. Navarante, P. Archer, C. Mazhude, D. Scott, R. O'Connell, J. Wong (L), G. Boddy (P); Sheffield Children's Hospital: F. Shackley, R. Lakshman, J. Hobbs, G. Ball (L), G. Kudesia (L), J. Bane (P), D. Painter (P); Ealing Hospital NHS Trust: K. Sloper, V. Shah, A. Cheng (P), A. Aali (L); King's College Hospital, London: C. Ball, S. Hawkins, D. Nayagam, A. Waters, S. Doshi (P); Newham University Hospital: S. Liebeschuetz, B. Sodiende, D. Shingadia, S. Wong, J. Swan (P), Z. Shah (P); Royal Devon and Exeter Hospital: A. Collinson, C. Hayes, J. King (L), K. O'Connor (L); Imperial College Healthcare NHS Trust, London: G. Tudor-Williams, H. Lyall, K. Fidler, S. Walters, C. Foster, D. Hamadache, C. Newbould, C. Monrose, S. Campbell, S. Yeung, J. Cohen, N. Martinez-Allier, D. Melvin, J. Dodge, S. Welch, G. Tatum, A. Gordon, S. Kaye (L), D. Muir (L), D. Patel (P); Great Ormond Street Hospital: V. Novelli, D. Gibb, D. Shingadia, K. Moshal, J. Lambert, N. Klein, J. Flynn, L. Farrelly, M. Clapson, L. Spencer, M. Depala (P); Institute of Child
Health, London: M. Jacobsen (L); John Radcliffe Hospital, Oxford: S. Segal, A. Pollard, D. Kelly, S. Yeadon, B. Ohene-Kena Y. Peng (L), T. Dong (L), Y. Peng (L), K. Jeffries (L), M. Snelling (P), Nottingham University Hospitals: A. Smyth, J. Smith; Chelsea and Westminster Hospital, London: B. Ward; Mortimer Market Centre, London: E. Jungmann; Doncaster Royal Infirmary: C. Ryan, K. Swaby; Health Protection Agency, London: A. Buckton (L); Health Protection Agency, Birmingham: E. Smit (L).

United States: Harlem Hospital Center: E.J. Abrams, S. Champion, A.D. Fernandez, D. Calo, L. Garrovillo, K. Swaminathan, T. Alford, M. Frere, Columbia University Laboratories, J. Navarra (P, Town Total Health); New York University School of Medicine: W. Borkowsky, S. Deygoo, T. Hastings, S. Akleh, T. Ilmet (L); Seattle Children's Hospital: A. Melvin, K. Mohan, G. Bowen (additional support by National Institutes of Health grant UL1 RR025014); University of South Florida: P.J. Emmanuel, J. Lujan-Zimmerman, C. Rodriguez, S. Johnson, A. Marion, C. Graisbery, D. Casey, G. Lewis; All Children's Hospital Laboratories; Oregon Health and Science University: J. Guzman-Cottrill, R. Croteau; San Juan City Hospital: M. Acevedo-Flores, M. Gonzalez, L. Angeli; L. Fabregas, Laboratory 053, P Valentin (P); State University of New York (SUNY) Upstate Medical University, Syracuse: L. Weiner, K.A. Contello, W. Holz, M. Butler; SUNY, Health Science Center at Stonybrook: S. Nachman, M.A. Kelly, D.M. Ferraro, University of North Carolina Retrovirology Laboratory; Howard University Hospital: S. Rana, C. Reed, E. Yeaǵley, A. Malheiro, J. Roa; Los Angeles County and University of Southern California Medical Center: M. Neely, A. Kovacs, L. Spencer, J. Homans, Y. Rodriguez Lozano, Maternal Child Virology Research Laboratory, Investigational Drug Service; South Florida Children's Diagnostic \& Treatment Center: A. Puga, G. Talero, R. Sellers; Broward General Medical Center, Uni- versity of Miami (L); University College of Florida College of Medicine-Gainesville: R. Lawrence; University of Rochester Pediatrics: G.A. Weinberg, B. Murante, S. Laverty; Miller Children's Hospital Long Beach: A. Deveikis, J. Batra, T. Chen, D. Michalik, J. Deville, K. Elkins, S. Marks, J. Jackson Alvarez, J. Palm, I. Fineanganofo (L), M. Keuth (L), L. Deveikis (L), W. Tomosada (P); Tulane University New Orleans: R. Van Dyke, T. Alchediak, M. Silio, C. Borne, S. Bradford, S. ElobyChildress (L), K. Nguyen (P); University of Florida/Jacksonville: M.H. Rathore, A. Alvarez; A. Mirza, S. Mahmoudi, M. Burke; University of Puerto Rico: I.L. Febo, L. Lugo, R. Santos; Children's Hospital Los Angeles: J.A. Church, T. Dunaway, C. Rodier; St Jude/University of Tennessee Health Science Center: P. Flynn, N. Patel, S. DiScenza, M. Donohoe; Western New England Maternal Pediatric Adolescent AIDS: K. Luzuriaga, D. Picard; Texas Children's Hospital: M. Kline, M.E. Paul, W.T. Shearer, C. McMullenJackson; Children's Memorial Hospital, Chicago: R. Yogev, E. Chadwick, E. Cagwin, K. Kabat; New Jersey Medical School: A. Dieudonne, P. Palumbo, J. Johnson; Robert Wood Johnson Medical School, New Brunswick: S. Gaur, L. Cerracchio; Columbia IMPAACT: M. Foca, A. Jurgrau, S. Vasquez Bonilla, G. Silva; Babies' Hospital, Columbia/Presbyterian Medical Center, New York: A. Gershon; University of Massachusetts Medical Center, Worcester: J. Sullivan; University of California-Los Angeles Medical Center: Y. Bryson; Children's Hospital, Seattle: L. Frenkel; University of North Carolina-Chapel Hill Virology Laboratory: S. Fiscus (L), J. Nelson (L).

\section{Trials Units/Support}

INSERM SC10 Paris: J.P. Aboulker, A. Compagnucci, G. Hadjou, S. Léonardo, Y. Riault, Y. Saïdi.

Medical Research Council Clinical Trials Unit, United Kingdom: A. Babiker, L. Buck, J.H. Darbyshire, L. Farrelly, S. Forcat, 
D.M. Gibb, H. Castro, L. Harper, L. Harrison, J. Horton, D. Johnson, S. Moore, C. Taylor, A.S. Walker.

Westat/NICHD: D. Collins, S. Buskirk, P. Kamara, C. Nesel, M. Johnson,

\section{A. Ferreira.}

Frontier Science: J. Hodge, J. Tutko, H. Sprenger.

IMPAACT: M. Hughes, M. Warshaw, P. Britto, C. Powell.

National Institute of Allergy and Infectious Diseases: R. DerSimonian, E. Handelsman (deceased).

PENTA Steering Committee: J.P. Aboulker, J. Ananworanich, A. Babiker, E. Belfrage,
S. Bernardi, S. Blanche, A.B. Bohlin, R. Bologna, D. Burger, K. Butler, G. Castelli-Gattinara, H. Castro, P. Clayden,

A. Compagnucci, J.H. Darbyshire, M. Debré, R. De Groot, M. Della Negra, A. De Rossi, A. Di Biagio, D. Duiculescu, A. Faye, V. Giacomet, C. Giaquinto (Chair), D.M. Gibb, I. Grosch-Wörner, M. Hainault, L. Harper, N. Klein, M. Lallemant, J. Levy, H. Lyall, M. Marczynska, M. Mardarescu, M.J. Mellado Pena, D. Nadal, L. Naver, T. Niehues, C. Peckham, D. Pillay, J. Popieska, J.T. Ramos Amador, L. Rosado, R. Rosso (deceased), C. Rudin, Y. Saïdi, H. Scherpbier, M. Sharland, M. Stevanovic, C. Thorne, P.A. Tovo,
G. Tudor-Williams, A.S. Walker, S. Welch, U. Wintergerst, N. Valerius.

\section{Additional Contributors}

Methodological advice was provided by C. Poole and S.R. Cole, University of North Carolina-Chapel Hill. Manuscript proofreading and suggestions were provided by R.J. McCulloh, Children's Mercy Hospitals and Clinics, University of Missouri-Kansas City.

\section{Participants, Families, Staff}

We thank all the children, families, and staff from the centers participating in the PENPACT- 1 trial.

\section{REFERENCES}

1. Joint United Nations Programme on HIV/AIDS. Global Report: UNAIDS report on the global AIDS epidemic 2013. Geneva, Switzerland: WHO Library Cataloguing-inPublication Data; 2013. Available at: http:// www.unaids.org/en/media/unaids/contentassets/documents/epidemiology/2013/gr2013/ UNAIDS_Global_Report_2013_en.pdf. Accessed October 14, 2013

2. Patel K, Hernán MA, Williams PL, et al; Pediatric AIDS Clinical Trials Group 219/219C Study Team. Long-term effectiveness of highly active antiretroviral therapy on the survival of children and adolescents with HIV infection: a 10-year follow-up study. Clin Infect Dis. 2008;46(4):507-515

3. Dunn D; HIV Paediatric Prognostic Markers Collaborative Study Group. Short-term risk of disease progression in HIV-1-infected children receiving no antiretroviral therapy or zidovudine monotherapy: a metaanalysis. Lancet. 2003;362(9396):1605-1611

4. Resino S, Micheloud D, Larrú B, et al; Spanish Group of Paediatric HIV Infection. Immunological recovery and metabolic disorders in severe immunodeficiency HIV type 1-infected children on highly active antiretroviral therapy. AIDS Res Hum Retroviruses. 2008;24(12):1477-1484

5. Wong FL, Hsu AJ, Pham PA, Siberry GK, Hutton N, Agwu AL. Antiretroviral treatment strategies in highly treatment experienced perinatally HIV-infected youth. Pediatr Infect Dis J. 2012;31(12):1279-1283

6. van Rossum AM, Geelen SP, Hartwig NG et al. Results of 2 years of treatment with protease-inhibitor-containing antiretroviral therapy in dutch children infected with human immunodeficiency virus type 1. Clin Infect Dis. 2002;34(7):1008-1016

7. Merzel C, VanDevanter N, Irvine M. Adherence to antiretroviral therapy among older children and adolescents with HIV: a qualitative study of psychosocial contexts. AIDS Patient Care STDS. 2008;22(12):977-987

8. Violari A, Cotton MF, Gibb DM, et al; CHER Study Team. Early antiretroviral therapy and mortality among HIV-infected infants. N Engl J Med. 2008;359(21):2233-2244

9. Penazzato M, Prendergast AJ, Muhe LM, Tindyebwa D, Abrams E. Optimisation of antiretroviral therapy in HIV-infected children under 3 years of age. Cochrane Database Syst Rev. 2014;5:CD004772

10. Laughton B, Cornell M, Grove D, et al. Early antiretroviral therapy improves neurodevelopmental outcomes in infants. AIDS. 2012;26(13):1685-1690

11. Shiau S, Arpadi S, Strehlau R, et al. Initiation of antiretroviral therapy before 6 months of age is associated with faster growth recovery in South African children perinatally infected with human immunodeficiency virus. J Pediatr. 2013;162(6):11381145, 1145.e1131-1132

12. Dabis $\mathrm{F}$, Elenga $\mathrm{N}$, Meda $\mathrm{N}$, et al; DITRAME Study Group. 18-Month mortality and perinatal exposure to zidovudine in West Africa. AIDS. 2001;15(6):771-779

13. HIV Paediatric Prognostic Markers Collaborative Study. Predictive value of absolute CD4 cell count for disease progression in untreated HIV-1-infected children. AIDS. 2006;20 (9):1289-1294

14. Puthanakit T, Ananworanich J, Vonthanak S, et al; PREDICT Study Group. Cognitive function and neurodevelopmental outcomes in HIV-infected Children older than 1 year of age randomized to early versus deferred antiretroviral therapy: the PREDICT neurodevelopmental study. Pediatr Infect Dis J. 2013;32(5):501-508

15. Puthanakit T, Saphonn V, Ananworanich J, et al; PREDICT Study Group. Early versus deferred antiretroviral therapy for children older than 1 year infected with HIV (PREDICT): a multicentre, randomised, openlabel trial. Lancet Infect Dis. 2012;12(12): 933-941

16. Hengel RL, Jones BM, Kennedy MS, Hubbard MR, McDougal JS. Lymphocyte kinetics and precursor frequency-dependent recovery of CD4(+)CD45RA(+)CD62L(+) naive T cells following triple-drug therapy for HIV type 1 infection. AIDS Res Hum Retroviruses. 1999; 15(5):435-443

17. Kaufmann GR, Bloch M, Finlayson R, Zaunders J, Smith D, Cooper DA. The extent of HIV-1related immunodeficiency and age predict the long-term CD4 T lymphocyte response to potent antiretroviral therapy. AIDS. 2002;16 (3):359-367

18. Soh CH, Oleske JM, Brady MT, et al; Pediatric AIDS Clinical Trials Group. Long-term effects of protease-inhibitor-based combination therapy on CD4 T-cell recovery in HIV-1-infected children and adolescents. Lancet. 2003;362(9401):2045-2051 
19. Walker AS, Doerholt K, Sharland M, Gibb DM; Collaborative HIV Paediatric Study (CHIPS) Steering Committee. Response to highly active antiretroviral therapy varies with age: the UK and Ireland Collaborative HIV Paediatric Study. AIDS. 2004;18(14): 1915-1924

20. Newell ML, Patel D, Goetghebuer T, Thorne C; European Collaborative Study. CD4 cell response to antiretroviral therapy in children with vertically acquired HIV infection: is it associated with age at initiation? J Infect Dis. 2006;193(7):954-962

21. Patel K, Hernán MA, Williams PL, et al; Pediatric AIDS Clinical Trials Group 219/219C Study Team. Long-term effects of highly active antiretroviral therapy on CD4+ cell evolution among children and adolescents infected with HIV: 5 years and counting. Clin Infect Dis. 2008;46(11):1751-1760

22. Weinberg $A$, Dickover $R$, Britto $P$, et al; PACTG 1021 team. Continuous improvement in the immune system of HIV-infected children on prolonged antiretroviral therapy. AIDS. 2008;22(17):2267-2277

23. Edmonds A, Yotebieng M, Lusiama J, et al. Quantification of CD4 responses to combined antiretroviral therapy over 5 years among HIV-infected children in Kinshasa, Democratic Republic of Congo. I Acquir Immune Defic Syndr. 2012;61(1):90-98

24. Lewis J, Walker AS, Castro $\mathrm{H}$, et al. Age and CD4 count at initiation of antiretroviral therapy in HIV-infected children: effects on long-term T-cell reconstitution. J Infect Dis. 2012;205(4):548-556

25. Gougeon ML, Lecoeur $H$, Dulioust $A$, et al. Programmed cell death in peripheral lymphocytes from HIV-infected persons: increased susceptibility to apoptosis of CD4 and CD8 T cells correlates with lymphocyte activation and with disease progression. J Immunol. 1996;156(9):3509-3520

26. Ruel T, Ssewanyana I, Achan J, et al. Dynamics of $T$ cell activation accompanying CD4 recovery in antiretroviral treated HIVinfected Ugandan children. Clin Immunol. 2009;131(3):410-414

27. Cohen Stuart JW, Slieker WA, Rijkers GT, et al. Early recovery of CD4+ T lymphocytes in children on highly active antiretroviral therapy. Dutch study group for children with HIV infections. AIDS. 1998;12(16):21552159

28. Chavan S, Bennuri B, Kharbanda M, Chandrasekaran A, Bakshi S, Pahwa S. Evaluation of $T$ cell receptor gene rearrangement excision circles after antiretroviral therapy in children infected with human immunodeficiency virus. J Infect Dis. 2001; 183(10):1445-1454
29. De Beaudrap P, Rouet F, Fassinou P, et al. CD4 cell response before and after HAART initiation according to viral load and growth indicators in HIV-1-infected children in Abidjan, Côte d'Ivoire. J Acquir Immune Defic Syndr. 2008;49(1):70-76

30. Shearer WT, Rosenblatt HM, Gelman RS, et al; Pediatric AIDS Clinical Trials Group. Lymphocyte subsets in healthy children from birth through 18 years of age: the Pediatric AIDS Clinical Trials Group P1009 study. J Allergy Clin Immunol. 2003;112(5): 973-980

31. Babiker A, Castro nee Green H, Compagnucci A, et al; PENPACT-1 (PENTA 9/PACTG 390) Study Team. First-line antiretroviral therapy with a protease inhibitor versus non-nucleoside reverse transcriptase inhibitor and switch at higher versus low viral load in HIV-infected children: an open-label, randomised phase 2/3 trial. Lancet Infect Dis. 2011;11(4):273283

32. World Health Organization. WHO case definitions of HIV for surveillance and revised clinical staging and immunological classification of HIV-related disease in adults and children. Geneva, Switzerland: WHO Library Cataloging-in-Publication Data; 2007. Available at: http://www.who.int/hiv/pub/guidelines/HIVstaging150307.pdf. Accessed October 26, 2013

33. Waecker NJ Jr, Ascher DP, Robb ML, et al; The Military Pediatric HIV Consortium. Age-adjusted CD4+ Iymphocyte parameters in healthy children at risk for infection with the human immunodeficiency virus. Clin Infect Dis. 1993;17 (1): $123-125$

34. Centers for Disease Control and Prevention. 1994 Revised classification system for human immunodeficiency virus infection in children less than 13 years of age. MMWR Morb Mortal Wkly Rep. 1994;43(R-12):1-10 Available at: http:// www.cdc.gov/mmwr/preview/mmwrhtml/ 00032890.htm. Accessed 0ctober 26, 2013

35. Centers for Disease Control and Prevention. Revised surveillance case definitions for HIV infection among adults, adolescents, and children aged $<18$ months and for HIV infection and AIDS among children aged 18 months to $<13$ years-United States, 2008. MMWR Morb Mortal Wkly Rep. December 5, 2008 2008;57(RR10):1-8. Available at: http://www.cdc.gov/MMWr/ preview/mmwrhtml/rr5710a1.htm. Accessed October 26, 2013

36. Zou G. A modified poisson regression approach to prospective studies with binary data. Am J Epidemiol. 2004;159 (7) :702-706
37. Spiegelman D, Hertzmark E. Easy SAS calculations for risk or prevalence ratios and differences. Am J Epidemiol. 2005;162(3): 199-200

38. Greenland S, Pearl J, Robins JM. Causal diagrams for epidemiologic research. Epidemiology. 1999;10(1):37-48

39. Textor J, Hardt J, Knüppel S. DAGitty: a graphical tool for analyzing causal diagrams. Epidemiology. 2011;22(5):745

40. Cole SR, Hernán MA. Fallibility in estimating direct effects. Int J Epidemiol. 2002;31(1): 163-165

41. Storer BE, Gooley TA, Jones MP. Adjusted estimates for time-to-event endpoints. Lifetime Data Anal. 2008;14(4):484-495

42. Toh S, Hernán MA. Causal inference from Iongitudinal studies with baseline randomization. Int J Biostat. 2008;4(1):22

43. Panel on Antiretroviral Therapy and Medical Management of HIV-Infected Children. Guidelines for the Use of Antiretroviral Agents in Pediatric HIV Infection. 2014 Available at: http://aidsinfo.nih.gov/contentfiles/lvguidelines/pediatricguidelines. pdf. Accessed April 18, 2014

44. Panel on Antiretroviral Guidelines for Adults and Adolescents. Guidelines for the Use of Antiretroviral Agents in HIV-1Infected Adults and Adolescents. 2014: Department of Health and Human Services. Available at: http://aidsinfo.nih.gov/contentfiles/ Ivguidelines/adultandadolescentǵl.pdf. Accessed June 18, 2014

45. Zolopa A, Andersen J, Powderly W, et al. Early antiretroviral therapy reduces AIDS progression/death in individuals with acute opportunistic infections: a multicenter randomized strategy trial. PLOS ONE. 2009; 4(5): e5575

46. Hammer SM, Squires KE, Hughes MD, et al A controlled trial of two nucleoside analogues plus indinavir in persons with human immunodeficiency virus infection and CD4 cell counts of 200 per cubic millimeter or less. AIDS Clinical Trials Group 320 Study Team. N Engl J Med. 1997;337(11): 725-733

47. Severe P, Juste MA, Ambroise A, et al. Early versus standard antiretroviral therapy for HIV-infected adults in Haiti. N Engl J Med. 2010;363(3):257-265

48. Kitahata MM, Gange SJ, Abraham AG, et al; NA-ACCORD Investigators. Effect of early versus deferred antiretroviral therapy for HIV on survival. N Engl J Med. 2009;360(18): 1815-1826

49. Sterne JA, May M, Costaǵliola D, et al; When To Start Consortium. Timing of initiation of antiretroviral therapy in AIDS-free HIV-1infected patients: a collaborative analysis 
of 18 HIV cohort studies. Lancet. 2009;373 (9672):1352-1363

50. Writing Committee for the CASCADE Collaboration. Timing of HAART initiation and clinical outcomes in human immunodeficiency virus type 1 seroconverters. Arch Intern Med. 2011;171(17):1560-1569

51. Cain LE, Logan R, Robins JM, et al; HIVCAUSAL Collaboration. When to initiate combined antiretroviral therapy to reduce mortality and AIDS-defining illness in HIV- infected persons in developed countries: an observational study. Ann Intern Med. 2011;154(8):509-515

52. Le T, Wright EJ, Smith DM, et al. Enhanced CD4+ T-cell recovery with earlier HIV-1 antiretroviral therapy. N Engl J Med. 2013; 368(3):218-230

53. Cohen MS, Chen YQ, McCauley M, et al; HPTN 052 Study Team. Prevention of HIV-1 infection with early antiretroviral therapy. N Engl J Med. 2011;365(6):493-505
54. Flynn PM, Rudy BJ, Lindsey JC, et al; PACTG 381 Study Team. Long-term observation of adolescents initiating HAART therapy: threeyear follow-up. AIDS Res Hum Retroviruses. 2007;23(10):1208-1214

55. Uy J, Armon C, Buchacz K, Wood K, Brooks JT; HOPS Investigators. Initiation of HAART at higher CD4 cell counts is associated with a lower frequency of antiretroviral drug resistance mutations at virologic failure. J Acquir Immune Defic Syndr. 2009;51(4):450-453

\begin{abstract}
(Continued from first page)
Dr Yin conceptualized the study aims, designed the analytical plan, conducted all data analyses, interpreted the results, and drafted and revised the manuscript Ms Warshaw contributed to development of the study aims, guided the analytical plan, guided and supervised data analysis, contributed to results interpretation, and reviewed and revised the manuscript; Dr Miller guided the analytical plan, guided data analyses, contributed to results interpretation, and reviewed and revised the manuscript; Ms Castro, Ms Harper, Dr Klein, and Dr Lewis contributed to interpretation of results and reviewed and revised the manuscript; Dr. Fiscus conducted laboratory analysis of specimens and reviewed and revised the manuscript; Ms Harrison contributed to the analytical plan, contributed to interpretation of results, and reviewed and revised the manuscript; Dr Melvin was Pediatric AIDS Clinical Trials Group co-chair of the study, contributed to development of study aims, acquired data, and reviewed the manuscript; Dr Tudor-Williams was Paediatric European Network for Treatment of AIDS co-chair of the study, contributed to development of study aims, acquired data, and reviewed and revised the manuscript; Dr McKinney was Pediatric AIDS Clinical Trials Group cochair of the study, contributed to development of study aims and analytical plan, acquired data, guided data analysis, interpreted results, and reviewed and revised the manuscript; and all authors approved the final manuscript as submitted.
\end{abstract}

Clinical Trial Registration: This trial has been registered with www.isrctn.org (ISRCTN73318385)

www.pediatrics.org/cgi/doi/10.1542/peds.2014-0527

doi:10.1542/peds.2014-0527

Accepted for publication Jul 24, 2014

Address correspondence to Dwight E. Yin, MD, MPH, Division of Infectious Diseases, Department of Pediatrics, Children's Mercy Hospitals and Clinics, 2401 Gillham Rd, Kansas City, M0 64108. E-mail: deyin@cmh.edu

PEDIATRICS (ISSN Numbers: Print, 0031-4005; Online, 1098-4275)

Copyright (C) 2014 by the American Academy of Pediatrics

FINANCIAL DISCLOSURE: Dr McKinney serves on an advisory board for Janssen Pharmaceuticals; the other authors have indicated they have no financial relationships relevant to this article to disclose.

FUNDING: This work was supported by the Eunice Kennedy Shriver National Institute of Child Health and Human Development (NICHD) training grants to the Department of Pediatrics, Duke University Medical Center (T32 HD043029) and the Division of Infectious Diseases, Department of Pediatrics, Duke University Medical Center (T32 HD060558) The PENPACT-1 trial was sponsored jointly by the Paediatric European Network for Treatment of AIDS (PENTA) Foundation, AgènceNationale de Recherchesur le Sidaet les hepatitis virales (ANRS), and the Pediatric AIDS Clinical Trials Group (PACTG), subsequently named the International Maternal Pediatric Adolescent AIDS Clinical Trials Group (IMPAACT). Overall support for PACTG/IMPAACT was provided by the National Institute of Allergy and Infectious Diseases (NIAID; U01 Al068632), the NICHD, and the National Institute of Mental Health (Al068632). The content is solely the responsibility of the authors and does not necessarily represent the official views of the National Institutes of Health. This work was supported by the Statistical and Data Analysis Center at Harvard School of Public Health, under the National Institute of Allergy and Infectious Diseases cooperative agreement 5 U01 Al41110 with the PACTG and 1 U01 Al068616 with the IMPAACT Group. Support of the sites was provided by the National Institute of Allergy and Infectious Diseases and the NICHD International and Domestic Pediatric and Maternal HIV Clinical Trials Network funded by NICHD (contract number N01-DK-9-001/ HHSN267200800001C). PENTA is a coordinated action of the European Commission/European Union, supported by the seventh framework programme (FP7/2007-2013) under the Eurocoord grant agreement 260694, the sixth framework contract LSHP-CT-2006-018865, the fifth framework programme contract QLK2-CT-2000-00150, and by the PENTA Foundation. UK clinical sites were supported by a grant from the Medical Research Council (MRC); those in Italy by a grant from the Istituto Superiore di Sanita—Progetto Terapia Antivirale 2004, 2005. GlaxoSmithKline and Bristol-Myers Squibb provided drugs in Romania. The trial was coordinated by 4 trials centers: the MRC Clinical Trials Unit, London, United Kingdom (with support from the MRC); INSERM SC10, Paris, France (supported by ANRS); Frontier Science, New York, NY; and Westat, Rockville, MD (supported by NICHD). Funded by the National Institutes of Health (NIH).

POTENTIAL CONFLICT OF INTEREST: Dr McKinney is a member of several Data Safety Monitoring Boards for Gilead Sciences. The authors have indicated they have no potential conflicts of interest to disclose. 